\title{
Academics in the Armed Forces: A Critical Evaluation of English Language Curricula at the National Defence Academy (India)
}

\author{
N. S. Gundur \\ Government First Grade College, Alnavar, Dharwad, India \\ Email: gundur@rediffmail.com
}

\begin{abstract}
Academics in India has not paid much attention to the study of academic disciplines practised in Indian military institutes like the National Defence Academy (India). The present article, based upon the author's teaching experience at the NDA, gives an account of the English language/literature curricula for the cadets. While evaluating the programme against the backdrop of the identity of academics in the armed forces, it tries to discuss the problems of teaching English to the cadets and thereby suggests a curricular renewal in the light of changing military leadership in an age of globalization. Possible areas of research are also suggested for academic inquiry.
\end{abstract}

Index Terms —academics, armed forces, curriculum, English for military purposes

\section{INTRODUCTION}

Military academies form interesting objects of study from different academic perspectives. They can be exciting sites of readings not only in the aspects of military affairs but also in the educational and socio-cultural dimension. The teaching of various academic disciplines, behavioral patterns of cadets, their social identity, language, sexuality, physical training, etc can be some of the areas of research. But academics in India has not paid much attention to explore these themes of the armed forces. However, in the West many military academies have been studied and researched both by academics and military personnel. For example, The Armed Forces and Society ${ }^{1}$, an exclusive academic journal devoted to civil-military matters, has also been a platform for discussing military education. Research articles on topics such as teaching of sociology $y^{2}$, the social identity of the West Point cadets ${ }^{3}$, teaching poetry to soldiers ${ }^{4}$ and many more are cases in point. But in India such studies hardly find a place in academic discourse.

Though departments of strategic studies at various universities in India carry out research in defence studies, and magazines and journals in the area continue to exist, military academies like the Indian Military Academy (IMA), Dehra Dun, the National Defence Academy (NDA), Khadakwasla, Pune, the Officers Training Academy (OTA), Chennai, etc have hardly figured in their studies. Especially, very little research has been undertaken to address the issue of academic practices in the Indian military academies. One of the reasons for neglecting academics in military academies has been the fact that universities and colleges have no direct access to these institutions; military academies, in turn, maintain a deliberate distance from civil set-ups ${ }^{5}$, and the hegemony of military training in the academies prevails over academic training. Thus, they are isolated academic islands.

The study of academic disciplines especially in the National Defence Academy, Khadakwasla, Pune, is very important because the cadets can pass out from the academy only after the successful completion of their graduation along with basic military training. In fact, in the entire three-years-period of their stay, academic instruction to the cadets occupies $70 \%$ of the training and the rest is military training. The aim of the academy is to provide such cadets to the finishing academies who have undergone basic military training and at the same time are graduates. The academic side of the cadets training needs to be studied in terms of its relevance to the profession of armed forces. It is more than three decades since the introduction of the graduate course in the academy. In the context of a Revolution in Military Affairs and the changing role of military leadership, it is indeed worthwhile taking a stock of the academics

\footnotetext{
${ }^{1}$ The SAGE publication brings out a journal called Armed Forces and Society on behalf of Inter-University Seminar on Armed Forces and Society. The journal publishes academic/research oriented articles on the armed forces. The journal is available both online and in print.

${ }^{2}$ See David R. Segal and Morten G. Ender's (2008) "Sociology in military officers education". This essay introduces a special issue of Armed Forces \& Society examining sociology at military academies - Canada, France, Japan, the Netherlands, Russia, South Africa, Sweden, Turkey, the United States.

${ }^{3}$ Volker C. Franke (2000) in an article "Duty, honor, country: The social identity of West Point cadets" explores the effects of military socialization on the identity of cadets at the United States Military Academy.

${ }^{4}$ See Elizabeth D. Samet's (2002) "Teaching poetry to soldiers in a post-heroic age." It traces the close relationship between the literary imagination at play in poetry and the rhythms of war. Professor Elizabeth is Assistant Professor at the USMA, (USA).

${ }^{5}$ See Paul Higate and Ailsa Cameron (2006) "Reflexivity and researching the military" in which they opine that it is very difficult to research the military and securing the military's participation in volunteering research data.
} 
practised at the NDA. However, the present article does not discuss the entire configuration of the academic disciplines of the Academy. Instead, it examines only the discipline of English Studies.

One of the imperative areas that can be studied, as far as academic disciplines are concerned, is the English language teaching in the Academy. The study of the English language curriculum assumes importance precisely because English happens to be the official language of the Indian armed forces and it is also the medium of socialization, especially at the officers' level. Apart from the discipline and the spirit of camaraderie, what distinguishes the women in uniform is not only their English lifestyle but also their use of the English language as if it is their first language. Proficiency in the language is considered to be the hallmark of a military leader. The demands created by the new media and the changing role of the military leadership in the process of globalization expect a specialized training of the cadets in communication and in the English language skills. Accordingly developing the proficiency of the cadets in their English language skills is considered very important in the academies like the NDA. In the light of the present scenario let us examine the English language curriculum practised at the NDA as a case in point.

The objective of this paper is to give an account of the nature of English language teaching that is going on at the NDA. After giving a brief introduction to the Academy as a military institute, an attempt is made here to evaluate the present English language curriculum and the problems involved in the pedagogy; thereby a few curricular changes are suggested in the end.

\section{BACKGROUND}

The present NDA, a tri-services premier institute, was started as the Joint Services Wing at Clement town, Dehra Dun in January 1950. Later in 1954 it was shifted to Khadakwasla, Pune, with its new identity as the National Defence Academy ${ }^{6}$. Thus, the twice-born military establishment, perhaps the first of its kind in the world, trains the cadets for the Indian armed forces. The cadets are admitted to the academy after their +2 (Higher Secondary Education) through an all India selection procedure conducted by the Union Public Service Commission and the Service Selection Board, widely known in India as the UPSC and the SSB respectively. The academy, situated on a campus of about more than 8000 acres, trains the cadets both in military and academic education for their career as officers in the Indian armed forces - the Indian Army, Indian Navy and Indian Air Force. Cadets from some friendly foreign countries like Bhutan, Nepal, etc also are trained here.

A product of the NDA, popularly known as the EX-NDA, is a sort of 'brand' name in the Indian armed forces. What is important to notice is that the cadets undergo a rigorous and tough training curriculum. Once they join the academy they cannot visit their homes for six months. Their schedule is so hectic and tight that by the end of each day they are physically exhausted and mentally benumbed. The biggest challenge for the cadets is 'time management', which determines their stay at the Academy. Those who cannot cope with it quit it. The regimentation of the environment puts the junior cadets under mental strain. It is generally said in the academy that 'coming to the NDA is a culture shock'. First term cadets take almost five to six months to understand the ways of the Academy. Housed in 15 squadrons, each one of them named such as Alpha, Bravo, Charlie, etc, the cadets are baptized to militarism through a hierarchical system - senior cadets control the juniors.

The organizational structure of the Academy is that of a typical military cantonment. It is no use here outlining all the units of establishment except mention about the two branches particularly for our purpose here; they are Training Branch and Education Branch. The Training Branch coordinates the physical and the professional training of the cadets under the ATT (Army Training Team), NTT (Naval Training team), Air Force Training Team (AFTT) and PTT (Physical Training Team). Along with military training, academic instruction is also imparted to the cadets in the Education Branch for their graduate courses such as B.A., B.Sc. and B.Sc. (Computer Science). There are about eleven departments which include studies in Science, Basic Engineering, Social Sciences and Humanities. Each department, normally headed by a Professor who is a civilian academic, is staffed by both civilian instructors and service officers who are by and large from the Education Corps. Jawaharlal Nehru University, New Delhi, approves the syllabus designed from time to time by the respective departments at the academy and awards degrees to the cadets passing out at the end of each term.

However, the attitude of the cadets towards academics is generally not as encouraging as it is in the case of their military training. It is generally believed that "a thinking boy makes a poor soldier". Though academic training accounts for a lion's share in the overall training schedule, and every Command orders, "we are in different times, what we need is a thinking soldier", the hidden agenda is to orient the cadets more towards military training than academic training. Real education takes place in their squadrons not in the Education Branch. Their regimentation on the campus convinces them that they are here to train themselves to 'command' and not to be intellectuals or scientists or something of that sort. This attitude problematizes the whole practice of academics at the NDA. Another factor which adds to this problem is their physical fatigue caused by excessive physical training and punishments. The tired cadet finds the academic classes convenient zones for taking rest. Thus, academics is in constant conflict with military training at the NDA. Against this background we can proceed to understand the problems of teaching English to the cadets at the Academy.

${ }^{6}$ For the history of the NDA, see T.Raina's (1997) Cradle for military leadership: The national defence academy. 


\section{THE PRESENT ENGLISH CURRICULUM}

Language training is an important component of the cadets' education at the Academy. While all the foreign languages like Russian, German, French and even Arabic are taught in a single Department of Foreign Languages, the full-fledged English Department is an independent one. Having more than ten teachers (instructors), both civilian and service officers, and a language laboratory to aid their teaching, the English department plays an important role in the academy. Out of the total VI terms English is taught as a compulsory subject until the end of term IV. However, the English language teaching at the academy demands a relook and revaluation in the context of globalization where the very role of military leadership has undergone a paradigm shift.

Teaching English at the NDA offers a noticeable contrast to the teaching experience in civilian colleges. One of the problems in civilian colleges is that of numbers, especially in General English classes where a classroom may contain over a 100 students. But at the NDA the best part of teaching has been the cadet-teacher ratio; one teacher for thirty to thirty-five cadets in a lecture class; and in a tutorial class it is one teacher for fifteen to seventeen cadets. Besides, the NDA recruits meritorious teachers through the UPSC and provides them with the latest technology to aid their teaching. Apart from the audio-visual aids, such as the LCD projectors in many classrooms, the English Department has a stateof-the-art language laboratory. The teaching process is divided into lecture classes and tutorial classes. Lecture classes involve the teaching of literary texts and tutorial classes involve most of the language activities like writing skills, etc. Unlike civilian colleges where we find more lecture classes and less number of tutorial classes, here at the NDA an equal number of lectures and tutorial classes are designed to make the teaching-learning process very effective and conducive to task-based learning. Evaluation is done twice in a semester - a midterm test and an annual examination. The midterm test evaluates two skills -- speaking and writing. The annual exam evaluates the literary and critical competence of the cadets on the basis of their writing skills. The exams are conducted very strictly; malpractice during the exams results in ruthless punishment in the form of relegation. The defaulters will not be passed to the next term.

Though the teaching of academic subjects has some of the best features as mentioned above, the contents of English course used during the first four semesters need some curricular changes. A close look at the syllabi of English for the cadets shows that there is a mismatch between what is required for the cadets and what is being taught in English classrooms. The materials used, i.e., literary texts, for teaching English lack focus, relevance and significance. The texts prescribed for study do not seem to be geared to the specific goals to be achieved in the process of learning. What happens in the teaching of literary texts is a sort of content analysis which the cadets are able to do on their own, definitely without the help of bazaar (market) guides. Texts like Robert Dixson's Complete Course in English (2004) and RP Singh's (ed) An Anthology of English Essays (2000) prescribed for term I; R.K. Narayan's The Bachelor of Arts (1937) and the abridged version of Thomas Hardy's The Mayor of Casterbridge (1886) prescribed for term II, are too simple for the level of the cadets and these texts do not have any direct relevance to their learning needs. The teaching of selected poems from Palgrave's The Golden Treasury to cadets of term IV too serves no purpose. Philosophical poems like Thomas Gray's "Elegy Written in a Country Churchyard" seem too much for the cadets who are preparing themselves for fighting at the risk of their lives. However, G.B. Shaw's Pygmalion (1913) and Arms and the Man (1894) prescribed for term III are good picks. The cadets, as the present author's experience tells, enjoy Arms and the Man, which humorously makes a mockery of their own profession.

The most useful element in the learning process at the NDA is the tutorial class where language items like phonetics, grammatical exercises, letter writing, précis writing, lecturette, etc are taught. These items are necessary but, in addition to these, tutorial classes may focus on topics like public speaking, oratory, theory of rhetoric and the use of power point presentation, handling a (Press) conference, service writing, report writing, social conversation and etiquette, reading of prepared speeches, etc to develop the cadets' ability to communicate in a wide range of professional and social contexts. These are all missing from the present syllabus. Thus, with all its strengths the existing English language curriculum at the NDA leaves much to be desired.

Unlike their counterparts in civilian colleges, the cadets possess a fairly good command over the English language. It is quite obvious, since they are a selected lot screened through rigorous examinations by the Union Public Service Commission and the Service Selection Board. But it is also evident that the level of proficiency of the cadets' English deteriorates during the three years of their stay at the Academy. There are many reasons: their attitude towards academics changes once they spend a few months on the campus. They believe that their job is to fight, and studying is not their priority but a ritual. More than that, they take language-learning for granted. But it should be borne in mind that they are not there just for the academic training. They have to cope with a lot of military curriculum along with academics and their schedule is very "tight, broken down to the minute. Leisure is an occasional episode called liberty" (Missal, 2006). Hence, one of the challenges before the teaching community at the NDA is to teach the physically tired target group. 
Another challenge, especially before the Department of English, is to teach English against the interference of the DA lingo ${ }^{7}$. The lingo operates as an obstacle to the fluent English the cadets had acquired, before joining the Academy. Their vocabulary requirement restricts itself to a few formal expressions and a set of colloquialisms which sound telegraphic. Though it can be considered as a military register, it affects the communicative assets of the cadets as future officers who need to make use of language for their interpersonal skills. By the time the cadets pass out from the academy their English will have undergone, to use the cadets' own lingo, diprovement, not to speak of the enrichment of it. The NDA lingo they acquire becomes a part and parcel of their future communication.

The regimentation of the cadets' lives hardly leaves any space for exposure to language learning skills. There is no time to read enough and no fruitful interaction taking place in English except following the orders of the seniors. They suffer, linguistically speaking, a sort of arrested development. Hence, one of the concerns of the authorities at the NDA is the upgradation of the English language skills of the cadets. However, it must be acknowledged that there are some cadets who are quite interested to work on their English language skills against all odds.

\section{DISCUSSION}

There is a need for academic research in English language teaching pedagogy and the teaching of other academic disciplines at the NDA. The academy is an exciting site for academic exploration. However, it has hardly been an object of study. The above discussion illustrates how the present curriculum of English at the NDA needs to be restructured. The content of the syllabus is not in tune with the learning needs of the cadets. The present syllabus fails to specify the goals and the learning outcomes to be achieved.

As the cadets are trained in the academy for their specific profession, English for Military Purposes (EMP) should be the basis for curriculum designing. The present General English course should be replaced by EMP. Since languageneeds analysis is an important initial step of English for Specific Purposes (ESP) course ${ }^{8}$ research in Needs Analysis needs to be carried out before setting the goals of the course and specification of the syllabus content must be based on the results of the needs analysis.

Materials related to military life - both serious and humourous - have little space in the present curriculum. Military biographies such as Stanley Hirshson's General Patton: A Soldier's Life, and Humphrey Davis' Thimmaya of India can be used to inspire the cadets and novels like Joseph Heller's Catch 22 would not only relate the target group to their profession but also improve their language skills; such military literature is too obvious to be missed. Even from nonmilitary literature, interesting works of art, which can be of some use to the cadets, have hardly any place in the curriculum.

The very methodology of teaching at the NDA needs to be changed. Introducing role-plays, language games and such other task-based teaching techniques will not only prevent the cadets from dozing off (of course, they are tired after physical ragada) but also make them feel that learning language is fun. Film Studies can be a part of the syllabi; along with military biographies like General Patton a movie on Patton can be studied and the study of many war movies may add variety to the learning process.

Examinations may be so designed as to test the cadets' communicative competence in terms of skills -- listening, speaking, reading, and writing -- instead of testing the knowledge of the prescribed texts only. Thus, the teaching of English at the NDA should play a functional role and focus on developing the communicative competence of the cadets.

\section{CONCLUSION}

Military academies in India are interesting objects of study. Academic research has to take place at all levels on military academies in India. One of the potential areas of research has been 'language in the military set-up' - military register, English for Military Purposes, problems of teaching English at academies like the NDA and many more. The present English language curriculum at the National Defence Academy, which offers a contrasting study in relation to the teaching of English in civilian colleges, needs to be restructured so as to cater to the learning needs of the cadets. Undertaking an academic research on the lines suggested above is called for, especially in the English language teaching as it plays an important role in the shaping of military leadership in the context of globalization. A comparative perspective of teaching communication, language and literature in academies like the Royal Military Academy, Sandhurst (the UK), the United States Military Academy, West Point, etc and the NDA may be useful in curriculum planning.

\section{ACKNOWLEDGEMENT}

\footnotetext{
${ }^{7}$ The NDA lingo is a set of colloquialisms developed over a period of years. It is mostly a mixture of English and Hindi, which, therefore, is an interesting site of linguistic study. The present author has collected the lingo in the form of data, the interpretation of which was presented in the International Conference on Pragmatics, organized by IASE, Pune, held at the University of Pune, on 15-17 Dec 2006. See also Nigel Foster's (1993) The making of royal marine commando which provides a list of words the Royal Marines use. They are "incomprehensible to ninety per cent of the population in Britain, and only adds to the confusion when Royal goes abroad" (202).

${ }^{8}$ See Fraida Dublin and Elite Olshtain. (1996) Course design for needs analysis and syllabus writing, and there are lots of books and websites on ESP course design, for e.g. Dudley-Evans, T., and St John, M. (1998) Developments in ESP: A multi-disciplinary approach.
} 
The author would like to thank the University Grants Commission (UGC, New Delhi, India) which has provided the financial assistance to the Minor Research Project on English for Military Purposes: Needs Analysis of English Curriculum for the NDA Cadets. The present article is the result of preliminary investigation of the project. Thanks are also due to Dr. Simon Bernabas and Prof. G.B Sajjan who went through the early draft of this article and made suggestions.

\section{AUTHOR's NOTE}

The views expressed herein are those of the author and do not purport to reflect any official opinion or position of the National Defence Academy, India.

\section{REFERENCES}

[1] Armed forces and society http://afs.sagepub.com

[2] Dublin, Fraida and Elite Olshtain. (1996). Course design. New York: Oxford University Press.

[3] Dudley-Evans, T., and St John, M. (1998). Developments in ESP: A multi-disciplinary approach. Cambridge: Cambridge University Press.

[4] Foster, Nigel. (1993). The making of royal marine commando. London: Sidgwick and Jackson.

[5] Franke, Volker C. (2000). Duty, honor, country: The social identity of West Point cadets. Armed Forces and Society 2.26, 175 202.

[6] Higate, Paul and Ailsa Cameron. (2006). Reflexivity and researching the military. Armed Forces and Society 2. 32, $219-233$.

[7] Missal, S. (2006). Trishakti: the NDA Journal. Spring Term.

[8] Raina, T. (1999). Cradle for military leadership: The national defence academy: A history. Delhi: Oxford University Press.

[9] Samet, Elizabeth D. (2002). Teaching poetry to soldiers in a post- heroic age. Armed Forces and Society 29. 01; fall, 109-127.

[10] Segal, David R. and Morten G. Ender. (2008). Sociology in military officer education. Armed Forces and Society 35. 01, 3-15.

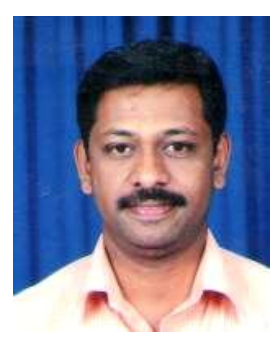

N.S Gundur (b.1976) is Assistant Professor of English, Government First Grade College, Alnavar, Dist. Dharwad (Karnataka State), India. He did his M.A in English (1999) and obtained his Ph. D (2004) from Karnatak University, Dharwad, Karnataka State, India.

He taught at the PG Department of English, Ahmednagar College (University of Pune), Ahmednagar, Maharashtra State (India). Before joining this department he also taught English to the cadets of the National Defence Academy, Khadakwasla, Pune (India) for four academic years.

$\mathrm{He}$ is the author of a book entitled Partition and Indian English Fiction (2008) and has also published many research articles in academic journals.

His areas of research interests are Literary and Cultural Studies, Linguistics, Indian Literature, ESP, and Film Studies. He also has researched the NDA-lingo (a typical linguistic register used by the cadets at the National Defence Academy, Khadakwasla, Pune). 